\title{
Comparison of different protein evaluation systems for growing pigs: Digestible crude protein, and total, faecal digestible and ileal digestible amino acid intakes as performance response predictors
}

\author{
JARMO VALAJA
}

VALAJA, J. 1994. Comparison of different protein evaluation systems for growing pigs: Digestible crude protein, and total, faecal digestible and ileal digestible amino acid intakes as performance response predictors. Agricultural Science in Finland 3: 429-437. (Department of Animal Science, P.O. Box 28, FIN-00014 University of Helsinki, Finland.)

\begin{abstract}
The validity of apparent faecal digestible crude protein and total, apparent faecal or ileal digestible amino acid intakes (lysine, threonine and methionine) as animal performance predictors was evaluated on the basis of digestibility coefficients obtained from the literature and performance and carcass parameter data from five different experiments on growing pigs. Correlations and regression equations were calculated between daily digestible crude protein or amino acid intakes and the performance and carcass parameters of the pigs.

No connection was found between digestible crude protein intake and the performance of the pigs. The correlations were highest between different lysine intakes and daily gain (DG) $(r=0.808-0.867, \mathrm{p}<0.001)$. Ileal digestible lysine intake correlated with the performance of the pigs better than did intakes of total or faecal digestible lysine. The feed conversion ratio (FCR) $(p<0.05)$, and the thickness of back (BF) $(p<0.001)$ and side fat (SF) $(p<0.001)$ correlated highly with ileal digestible lysine intake. The correlations between these parameters and total or faecal digestible lysine intakes were lower but also significant (total lysine: BF $\mathrm{p}<0.001$, SF $\mathrm{p}<0.01$ and faecal digestible lysine: BF $\mathrm{p}<0.01$, SF $\mathrm{p}<0.05$ ). The regression equations agreed well with the coefficients of correlation. Ileal digestible lysine intake explained changes of performance and carcass parameters better than did intakes of total and faecal digestible lysine.

The study confirms the advantage of using ileal digestibility coefficients of amino acids for detecting differences in the supply of amino acids from different feeds.
\end{abstract}

Key words: swine, lysine, methionine, threonine, digestibility, daily gain, feed conversion ratio, back fat, side fat

\section{Introduction}

The practical formulation of swine diets in Finland is usually based on the total supply of essential amino acids (lysine, threonine and sulphur containing amino acids) and digestible crude protein from dietary ingredients. However, wide variation is found in the digestibility of protein and amino acids between different feed ingredients determined either at terminal ileum or in faeces (JørGensen et al. 1984, SAUER and OzIMEK 1986, KNABE et al. 1989). For economic and environmental reasons, it is essential to take these differences into account in diet formulation. 
It is generally agreed that only the nitrogen absorbed from the small intestine has nutritional value for pigs. ZeBrowSKA (1973) showed that nitrogen infused into the terminal part of the ileum was digested, but that it was almost completely excreted in urine. Comparisons have been made between the ileal and faecal digestibilities of amino acids in different feeds (JøRGENSEN et al. 1984, 1985); the apparent faecal digestibility of amino acids usually gives higher values than does ileal digestibility and may overestimate the amount of amino acids available for protein synthesis. Microbial fermentation and protein synthesis in the large intestine also modify the amino acid composition of faeces as compared with the undigested dietary protein residue (MASON 1984).

Protein evaluation system currently used in Finland is based on the apparent faecal digestibility of protein and the total amount of amino acids in the diet (SALO et al. 1990). In feed tables used in Denmark apparent faecal digestibility of each amino acid is calculated from the total content of amino acids and the faecal digestibility of nitrogen (ANDERSEN and JUST 1983). Recently published Dutch feed tables also report the apparent ileal digestibility coefficents of amino acids (CVB 1991). Many authors have concluded that amino acid digestibilities measured at the terminal ileal are the most appropriate (e.g. TANKSLEY and Knabe 1984, Sauer and Ozimek 1986). However, BATTERHAM et al. (1990a, 1990b) have queried the validity of measuring the ileal digestibility of some heat-treated feedstuffs. Only a few experiments have been conducted to compare the faecal or ileal digestibility values with animal performance responses (JUST et al. 1985, DIERICK et al. 1988, WISEMAN et al. 1991), and they give no clear answer as to which method is the most reliable for practical diet formulation.

In 1992, the Ministry of Agriculture and Forestry set up a project to update Finnish feed tables for farm animals. As part of the project, the different protein evaluation systems for growing pigs were studied. The investigation reported in this paper compares a number of these systems as predictors of performance and carcass parameter responses.

\section{Material and methods}

\section{Protein evaluation systems}

Four protein evaluation systems were selected: apparent digestible crude protein, total amino acids (lysine, methionine and threonine), apparent faecal digestible amino acids and apparent ileal digestible amino acids. The apparent faecal digestible crude protein content of the diet was calculated from the analysed crude protein content of the dietary ingredients and the apparent faecal digestibility values taken from the feed tables currently used in Finland (SALO et al. 1990). The total content of amino acids in the diet was calculated from the analysed amino acid content of the feed ingredients. The apparent faecal digestible amino acid content was calculated from the amino acid content and the table values of the apparent faecal digestibility of crude protein in dietary ingredients (SALO et al. 1990). The apparent ileal digestible amino acid content was calculated using the digestibility coefficients reported in the Dutch feeding tables (CVB 1991).

\section{Data set}

The data were collected from feeding trials conducted on growing pigs at the Swine Research Station of the Agricultural Research Centre of Finland in 1986-92. Five feeding trials comprising 23 treatments and 604 pigs were chosen for the investigation (Table 1). In the experiments different protein sources were compared, feeding was restricted (calculated equal energy intake), the amino acid composition of feed ingredients in the experimental diets was analysed and the use of synthetic amino acids in the diets was limited. One treatment mean served as an experimental unit.

In all experiments the control diet consisted of barley, soyabean meal and a mixture of minerals and vitamins. The experimental diets comprised mainly domestic protein ingredients, e.g. rapeseed meal, meat and bone meal, peas, skim milk 
Table 1. Description of data set.

\begin{tabular}{|c|c|c|c|c|}
\hline Experiment & Treatments & Animals & Feeding scale & Reference \\
\hline 1. Fish meal & $\begin{array}{l}\text { xp., } 1986 \\
\text { SBM } 20 \% \\
\text { SBM } 16 / \text { FM } 2.7 \% \\
\text { SBM } 10 / \text { FM } 6.5 \% \\
\text { FM } 13 \%\end{array}$ & $\begin{array}{l}112, \\
28 / \operatorname{trm}\end{array}$ & $1.2-3.0 \mathrm{FU} / \mathrm{d}$ & VALAJA et al. (1992) \\
\hline 2. Meat and & $\begin{array}{l}\text { one meal exp., } 1987 \\
\text { SBM 16.5\% } \\
\text { SBM 10/MBM (Plant 1) } 7.5 \% \\
\text { SBM 3/MBM (Plant 1) } 15 \% \\
\text { SBM 10/MBM (Plant 2) } 7.5 \% \\
\text { SBM 3/MBM (Plant 2) } 15 \%\end{array}$ & $\begin{array}{l}140 \\
28 / \text { trm }\end{array}$ & $1.2-2.8 \mathrm{FU} / \mathrm{d}$ & ALAVIUHKOLA (1989) \\
\hline 3. Domestic & $\begin{array}{l}\text { rotein sources exp. } 1,1988 \\
\text { SBM 14/FM } 2 \% \\
\text { RSM 22/P 11\% } \\
\text { RSM 18/P 9/MBM 3\% } \\
\text { RSM 18/P 9/PY 2\% } \\
\text { RSM 18.7/P 9.3/MBM 2/MP 0.5\% } \\
\text { RSM 15.3/P 7.7/MBM 3/PY 2/MP } 0.5 \%\end{array}$ & $\begin{array}{l}144 \\
24 / \text { trm }\end{array}$ & $1.2-2.8 \mathrm{FU} / \mathrm{d}$ & SUOMI and IMMONEN (1989) \\
\hline 4. Domestic & $\begin{array}{l}\text { rotein sources exp. } 2,1989 \\
\text { SBM 14/FM 2\% } \\
\text { RSM 22/P 11\% } \\
\text { RSM 18/P 9/MBM 3\% } \\
\text { RSM 15.3/P 7.7/MBM 3/PY 2/MP 0.5\% }\end{array}$ & $\begin{array}{l}48, \\
12 / \mathrm{trm}\end{array}$ & $1.2-2.8 \mathrm{FU} / \mathrm{d}$ & SUOMI and IMMONEN (1989) \\
\hline 5. Rapeseed & $\begin{array}{l}\text { SBal exp., } 1992 \\
\text { SBM } 22.5 \% \text {, SBM } 14.9 \% \\
\text { SBM } 7.6 \text { /RSM } 15.1 \%, \text { SBM } 5.0 / \text { RSM } 9.9 \% \\
\text { RSM } 22.6 \% \text {, RSM } 14.9 \%\end{array}$ & $\begin{array}{l}160, \\
40 / \text { trm }\end{array}$ & $1.2-2.9 \mathrm{FU} / \mathrm{d}$ & SILJANDER-RASI (1993) \\
\hline
\end{tabular}

$\mathrm{SBM}=$ soyabean meal, $\mathrm{RSM}=$ rapeseed meal, $\mathrm{P}=$ peas, $\mathrm{MBM}=$ meat and bone meal, FM = fish meal, $\mathrm{PY}=$ pekilo yeast and $\mathrm{MP}=$ milk powder.

powder and pekilo yeast except in experiment 1 , where Norwegian fish meal was used. The nitrogen content of the dietary ingredients was determined by the Kjeldahl method, and amino acids were analysed by high performance liquid chromatography (HPLC) after hydrolysis with $6 \mathrm{~N}$ $\mathrm{HCl}$ at $110^{\circ} \mathrm{C}$ for $20 \mathrm{~h}$. The mean content of digestible crude protein, lysine, methionine and threonine was in the range 118-139, 6.5-8.9, 1.4 3.1 and $3.7-6.2 \mathrm{~g} / \mathrm{kg}$ feed in the five experiments, respectively (Table 2 ). The data set contained the treatment means of feed consumption, days in experiment, and performance and carcass com- position results including daily gain (DG), feed conversion ratio (FCR), back fat (BF) and side fat (SF) thickness, and per cent lean in valuable cuts (LVC) and in whole carcass (LC). The mean DG, FCR, BF, SF, LVC and LC of the experiments were in the range $807-875 \mathrm{~g}, 2.61-2.96$ FU/kg, 22.3-25.4 mm, 15.5-19.3 mm, 78.7$80.8 \%$ and $49.9-54.5 \%$, respectively. The daily intake of digestible crude protein or essential amino acids (lysine, methionine and threonine) was calculated from the protein and amino acid composition of the diets and feed consumption of the pigs. 
Table 2. Mean dietary digestible crude protein, lysine, methionine and threonine contents and performance data of the experiments.

\begin{tabular}{|c|c|c|c|c|c|c|c|c|c|c|}
\hline Experiment & $\begin{array}{l}\text { DCP } \\
\mathrm{g} / \mathrm{kg}\end{array}$ & $\begin{array}{l}\text { LYS } \\
\mathrm{g} / \mathrm{kg}\end{array}$ & $\begin{array}{l}\mathrm{MET} \\
\mathrm{g} / \mathrm{kg}\end{array}$ & $\begin{array}{l}\text { THR } \\
\mathrm{g} / \mathrm{kg}\end{array}$ & $\begin{array}{c}\text { DG } \\
\text { g/day }\end{array}$ & $\begin{array}{c}\text { FCR } \\
\text { FU/kg }\end{array}$ & $\begin{array}{c}\mathrm{BF} \\
\mathrm{mm}\end{array}$ & $\begin{array}{c}\mathrm{SF} \\
\mathrm{mm}\end{array}$ & $\begin{array}{c}\text { LVC } \\
\%\end{array}$ & $\begin{array}{c}\mathrm{LC} \\
\%\end{array}$ \\
\hline 1. Fish meal & 139 & 8.9 & 3.1 & 6.2 & 875 & 2.61 & 22.3 & 15.5 & 80.6 & 50.2 \\
\hline 2. Meat and bone meal & 136 & 6.5 & 1.8 & 5.4 & 811 & 2.96 & 25.4 & 19.3 & 78.7 & 49.9 \\
\hline 3. Domestic protein sources 1 & 126 & 6.8 & 1.4 & 3.7 & 807 & 2.65 & 24.2 & 16.4 & 80.4 & 51.3 \\
\hline 4. Domestic protein sources 2 & 130 & 6.6 & 1.4 & 6.2 & 819 & 2.62 & 24.4 & 17.8 & 79.7 & 50.7 \\
\hline 5. Rapeseed meal', diet 1 & 136 & 8.7 & 1.9 & 6.1 & 844 & 2.72 & 23.7 & 16.8 & 80.8 & 54.5 \\
\hline diet 2 & 118 & 7.1 & 1.8 & 5.0 & & & & & & \\
\hline
\end{tabular}

DCP $=$ digestible crude protein, $\mathrm{LYS}=$ lysine, MET $=$ methionine, $\mathrm{THR}=$ threonine, $\mathrm{DG}=$ daily gain, $\mathrm{FCR}=\mathrm{feed}$ conversion ratio, $\mathrm{BF}=$ back fat, $\mathrm{SF}=$ side fat, $\mathrm{LVC}=$ lean in valuable cuts and $\mathrm{LC}=$ lean in carcass.

1. The experiment was divided into two periods, weeks 1-5 and weeks 6 to slaughter, with different diets. Performance and carcass parameter data are the means of the whole experiment.

\section{Analysis of data}

Statistical analysis of the data was performed using the SAS statistical package (SAS 1990). Pearson's linear correlation coefficients were calculated with the CORR procedure between the digestible crude protein or different amino acid intakes and the performance or carcass parameters. Linear regression equations were calculated with the REG procedure, using the digestible crude protein or amino acid intakes as independent variables and the different performance and carcass parameters as dependent variables. The significance of the coefficients of correlations and regressions was tested with a $t$ test $\left(\mathrm{H}_{0}\right.$ : the coefficient of regression or correlation $=0$ ). Partial correlation coefficients were calculated with the CANCORR procedure between the protein or amino acid intakes and the LVC or LC in order to eliminate the effect of year from the correlations, because the carcass dissection procedure was changed at the beginning of 1989 , resulting in an average $2 \%$ increase in carcass lean content. The year effect was partialled out of the correlations with the PARTIAL statement. The year of the experiment was included in the regression models where appropriate. Criteria for evaluation of systems were: significance of the coefficients of regression and correlation, and the fit of the regression models evaluated with the coefficients of determination $\left(\mathrm{R}^{2}\right)$.

\section{Results}

\section{Correlations}

The correlation matrix revealed large differences in the significance of the correlations between the digestible crude protein or differently assayed amino acid intakes and the performance and carcass parameters (Table 3). There was no connection between digestible crude protein intake and the performance or carcass parameters of the pigs. Significant correlations were found between amino acid intakes and the performance and carcass composition data although the differences in the power of correlations were quite small between the different amino acid intakes. However, amino acid intakes, especially that of lysine, which were calculated using ileal digestibility coefficients tended to correlate with the performance of the pigs better than did total or faecal digestible amino acid intakes. FCR correlated significantly with ileal digestible lysine intake $(r=-0.505$, $\mathrm{p}<0.05)$ and digestible crude protein intake $(\mathrm{r}=$ $-0.431, \mathrm{p}<0.05$ ). BF and SF also correlated significantly with ileal digestible lysine intakes $(\mathrm{BF}, \mathrm{r}=-0.731, \mathrm{p}<0.001 ; \mathrm{SF}, \mathrm{r}=-0.700$, $\mathrm{p}<0.001$ ); the correlations with total and faecal digestible lysine intakes were lower although significant (total lysine: BF, $\mathrm{r}=-0.687$, $\mathrm{p}<0.001$; SF, $r=-0.564, p<0.01$ and faecal digestible lysine: $\mathrm{BF}, \mathrm{r}=-0.626, \mathrm{p}<0.01 ; \mathrm{SF}, \mathrm{r}=-0.490, \mathrm{p}<0.05)$. 
Table 3. Correlation matrix between daily protein or amino acid intake and performance data ( 5 feeding trials, $n=23$, except for ileal amino acid intake $n=20$ ).

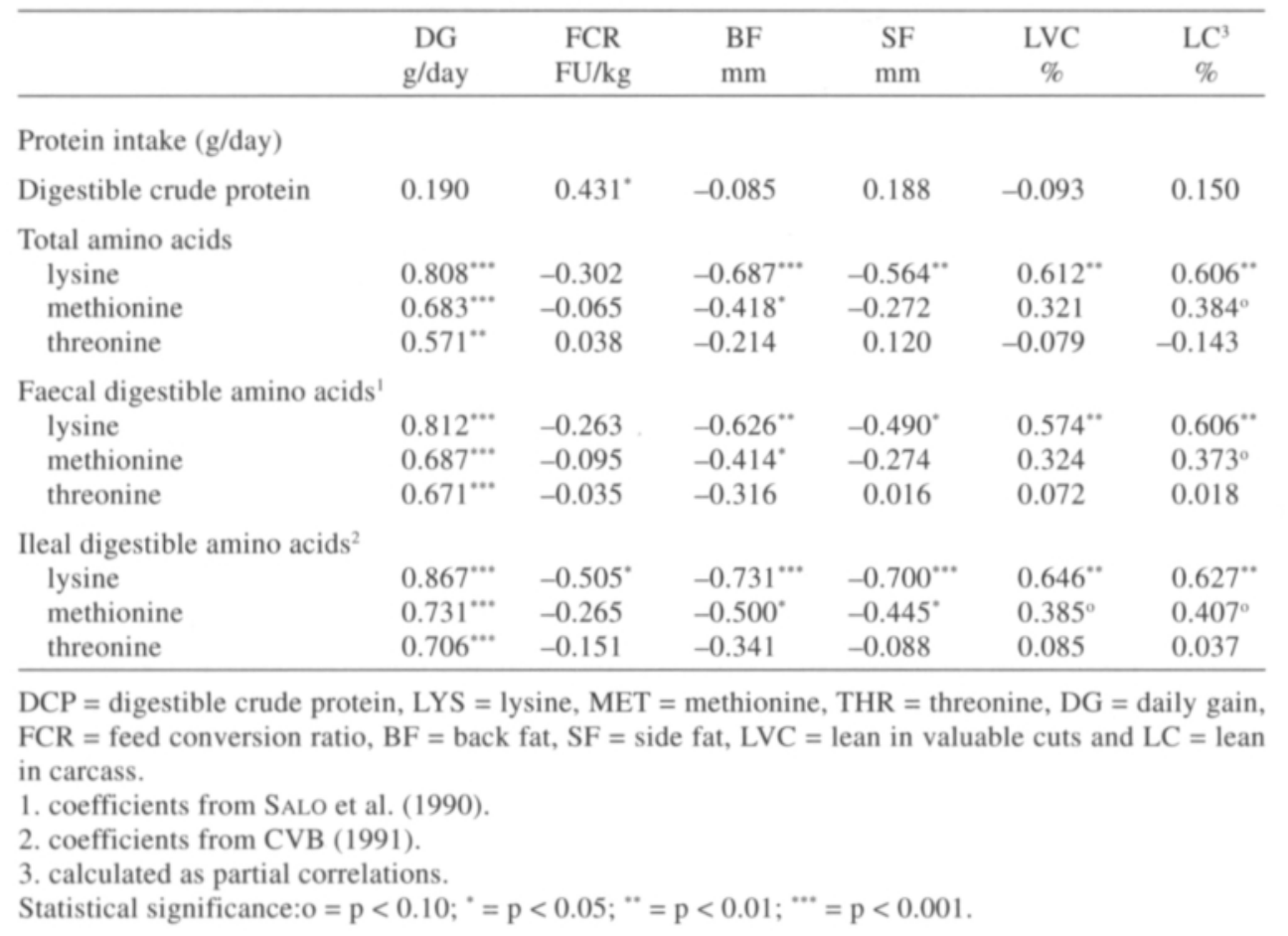

The highest correlations were found between daily lysine intakes and DG $(r=0.808-0.867$, $\mathrm{p}<0.001)$. Methionine and threonine intakes also paralleled DG but the correlations were lower than those between lysine intake and DG (methionine: $\mathrm{r}=0.683-0.731, \mathrm{p}<0.001$; threonine: $\mathrm{r}=0.571-0.706, \mathrm{p}<0.01$ (faecal) and $\mathrm{p}<0.001$ (ileal)). Daily lysine intakes also correlated well with other performance and carcass parameters except with FCR, whereas the correlations between methionine or threonine intakes and the performance and carcass parameters were clearly lower.

\section{Regression equations}

Since performance responses are a consequence of protein and amino acid intake it was logical to try and fit the data to the regression equations. Only the regression equations calculated for digestible crude protein and different lysine intakes are presented (Table 4) because the coefficients of determinations and regressions were extremely low for methionine and threonine intakes except in the case of DG, where $\mathrm{R}^{2}$ was 0.467 , 0.471 and 0.535 or $0.326,0.450$ and 0.499 with total, apparent faecal and ileal digestible methionine and threonine intakes, respectively. The year of the experiment was also included in the equations for LVC and LC, where it had a significant effect.

The regression equations for digestible crude protein and different lysine intakes were generally in agreement with the coefficients of correlation. The coefficients of regression calculated for digestible crude protein intake were very low and differed significantly from zero only for FCR ( $p<0.05)$, where the coefficient of determination was quite low, 0.185 . The best fit for the regression equations was found between the ileal digestible lysine intakes and performance re- 
Table 4. Coeffients of regression for performance and carcass data calculated as a function of daily protein or amino acid intakes (x1) (g/day). Experimental year (x2) was included in the regression equation where significant.

\begin{tabular}{|c|c|c|c|c|c|c|c|c|c|c|c|c|}
\hline & \multicolumn{3}{|c|}{ Digestible protein ( $\mathrm{g} /$ day) } & \multicolumn{3}{|c|}{ Total lysine (g/day) } & \multicolumn{3}{|c|}{ Faecal dig. lysine (g/day) } & \multicolumn{3}{|c|}{ Ileal dig. lysine (g/day) } \\
\hline & $\mathrm{X} 1$ & $\begin{array}{l}\text { Year } \\
(\mathrm{x} 2)\end{array}$ & $\mathrm{R}^{2}$ & $\mathrm{x} 1$ & $\begin{array}{l}\text { Year } \\
(\mathrm{x} 2)\end{array}$ & $\mathrm{R}^{2}$ & $\mathrm{x} 1$ & $\begin{array}{l}\text { Year } \\
(\mathrm{x} 2)\end{array}$ & $\mathrm{R}^{2}$ & $x 1$ & $\begin{array}{l}\text { Year } \\
(\mathrm{x} 2)\end{array}$ & $\mathrm{R}^{2}$ \\
\hline Daily gain, g/day & 0.332 & - & 0.036 & $11.6^{* *}$ & - & 0.653 & $11.8^{* \cdots}$ & - & 0.659 & $12.7^{\cdots *}$ & - & 0.751 \\
\hline FCR, FU/kg & $0.004^{*}$ & - & 0.185 & -0.022 & - & 0.091 & -0.019 & - & 0.069 & $-0.037^{*}$ & - & 0.255 \\
\hline Back fat, mm & -0.006 & - & 0.007 & $-0.387^{\cdots}$ & - & 0.472 & $-0.356^{* *}$ & - & 0.392 & $-0.429^{\cdots}$ & - & 0.534 \\
\hline Side fat, $\mathrm{mm}$ & 0.017 & - & 0.035 & $-0.417^{* *}$ & - & 0.319 & $-0.365^{\circ}$ & - & 0.239 & $-0.521^{\cdots}$ & - & 0.485 \\
\hline $\begin{array}{l}\text { Lean in valuable } \\
\text { cuts, } \%\end{array}$ & -0.016 & - & 0.081 & $0.238^{*}$ & $0.095^{\circ}$ & 0.331 & $0.221^{\circ}$ & $0.198^{\circ}$ & 0.287 & $0.299^{* *}$ & $0.178^{\circ}$ & 0.466 \\
\hline Lean in carcass, $\%$ & 0.008 & $0.795^{* *}$ & 0.780 & $0.216^{* *}$ & $0.783^{\cdots}$ & 0.851 & $0.219^{* *}$ & $0.796^{\cdots}$ & 0.850 & $0.241^{* *}$ & $0.774^{\cdots}$ & 0.865 \\
\hline
\end{tabular}

Statistical significance: $\mathrm{o}=\mathrm{p}<0.10{ }^{*}=\mathrm{p}<0.05 ;^{*}=\mathrm{p}<0.01 ;{ }^{\cdots}=\mathrm{p}<0.001$.

$\mathrm{FCR}=$ feed conversion ratio.

sponses. Only ileal digestible lysine intake paralleled FCR ( $\mathrm{p}<0.05)$, but $\mathrm{R}^{2}$ was quite low $(0.255)$. Ileal digestible lysine intake also explained well the variations in $\mathrm{BF}$ and $\mathrm{SF}\left(\mathrm{R}^{2}=0.534\right.$ and $0.485)$, and the coefficients of regression were highly significant $(\mathrm{p}<0.001)$. Total lysine intake produced a highly significant coefficient of regression with BF ( $p<0.001)$, but a less significant coefficient with SF ( $p<0.01)$. In both cases, the coefficients of regression for faecal digestible lysine intake were lower $(\mathrm{BF}, \mathrm{p}<0.01$; SF, $\mathrm{p}<0.05$ ). The coefficient of regression for ileal digestible lysine intake was higher with LVC $(\mathrm{p}<0.01)$ than was that for total or faecal digestible lysine intake $(p<0.05)$ and the coefficient of determination changed from 0.331 to 0.287 and 0.466 with total, faecal and ileal digestible lysine intakes, respectively. The best fit for the regression equations was found between the different lysine intakes and DG, where the coefficients of regression were highly significant $(\mathrm{p}<0.001)$. However, $\mathrm{R}^{2}$ tended to increase from total to ileal digestible intake $(0.653,0.659$ and 0.751 for the total, faecal and ileal digestible intakes, respectively).

\section{Discussion}

Calculations reported here were based on the assumption that the daily intake of protein and amino acids in the diets was below that required to meet the animal's potential daily body protein deposition, such that the performance responses were linearly related to the changes in intake. However, in four of the five experiments the content of digestible crude protein per unit of energy in the diets was in balance, and in these experiments the performance responses could not be related to the amount of digestible crude protein in the diets. This explains the poor correlations and regressions of digestible crude protein intake. In the case of the daily intake of lysine, the studies of HANRAHAN (1989) and MADSEN et al. (1991) confirm the validity of the assumption of a linear response. In all diets, lysine was the first limiting amino acid, and it resulted in a better fit to the regressions and higher correlations than did methionine or threonine intake. According to WANG and FULLER (1990), nitrogen retention is very closely related to the intake of the digestible first limiting amino acid.

In theory, digestibilities measured at the end of the ileum should give reliable estimates of the digestibility of nitrogen and single amino acids in feeds since only the amino acids absorbed before the ileo-caecal junction are available for protein synthesis, and the nitrogen absorbed from the large intestine is of no nutritive value to the animal (ZebrowsKa 1973). In the present calculations, ileal digestible amino acid intake was more closely related to the 
performance of the pigs than was digestible crude protein or total or faecal digestible amino acid intakes. This is consistent with the results of Just et al. (1985), who found a slightly higher correlation of ileal digestible crude protein and amino acids with deposited protein than with crude protein and amino acids disappearing in the whole digestive tract. The results obtained by DIERICK et al. (1988) gave even stronger evidence for the superiority of ileal over faecal digestibility values, as significant correlations of DG or FCR were found with ileal digestible protein ( $r=0.76$ for DG and -0.87 for FCR) but not with faecal digestible protein $(r=0.34$ for DG and -0.65 for FCR). Comparing diet formulations based on either the crude protein or the total or ileal digestible amino acid content, TANKSLEY and KNABE (1984) noted that the performance of pigs improved when ileal digestible amino acids were used. Low et al. (1982) and Moughan and SMITH (1985) also concluded that ileal digestibility is a good predictor of pig responses to the diets used.

It is nonetheless evident that in some feeds the ileal digestibility values fail to improve the diet formulation. BATTERHAM et al. (1990a, 1990b) observed that in certain heat-treated feeds, e.g. cottonseed meal and meat and bone meal, the ileal digestibility of lysine only accounts for some of the reduced availability. In the experiment of WISEMAN et al. (1991), the formulation of diets containing heat-treated fish meals based on the ileal or faecal digestibility coefficients of amino acids did not fully account for differences in the performance of the pigs compared with those fed untreated fish meal. The authors suggested that the absorbed amino acids were partly in an unavailable form for the animals. Moughan et al. (1991) also observed that the formulation of a barley, fish meal, and meat and bone meal diet based on the ileal digestibility of amino acids leads to overestimation of actual pig performance. In the present investigation, only the diets of the experiment 2 contained high amounts of heat-treated meat and bone meals and this did not affect the results. BATTERHAM (1992) suggested that amino acid availabilities could be measured with the slope-ratio assay instead of ileal digestibility assays. However, the method appears to be rather unreliable in practice (Moughan 1991).

Here, the faecal digestible amino acid content calculated from crude protein digestibility failed to show any improvement over the total amino acid content in BF and SF measurements. The calculation method is not appropriate in diet formulation since the relationship between the digestibility of nitrogen and an amino acid can vary from one feed to another (JøRGENSEN et al. 1984, WiSEMAN et al. 1991). LAPLACE et al. (1989) also found that the source of fibre in the diet had a significant negative interaction with the overall digestibility of amino acids and that additive effects occurred at the end of the small intestine. In addition, the mean ileal digestibilities of essential amino acids in soyabean meal, sunflower meal, fish meal, and meat and bone meal were found to be $12.7 \%$ units lower than the mean faecal digestibility values (JøRGENSEN et al. 1984). KNABE et al. (1989) pointed out that amino acid digestibilities could be predicted more precisely from ileal nitrogen digestibility than from the faecal nitrogen digestibility, but that neither ileal nor faecal nitrogen digestibility could be used with a high degree of certainty for predicting ileal amino acid digestibilities. ConwaY et al. (1990) likewise concluded that the requirement for threonine should be related to ileal digestibility and not to faecal digestibility. However, JøRGENSEN et al. (1985) found correlations ranging from 0.46 to 0.73 between overall crude protein digestibility and ileal digestibility of cystine, threonine, methionine and lysine.

The very low correlations of amino acid intake with FCR came as a surprise. However, BATTERHAM et al. (1981) suggested that FCR should be calculated on a carcass basis in order to eliminate the effect of gut fill from the results. Differences in gut fill are evident, especially in the cases of high fibre diets. This may have been the case in experiment 5, where rapeseed meal was included in the diets. The positive correlation between daily digestible crude protein intake and FCR was the result of the generally higher FCR 
in experiment 2, which had a biasing effect on the correlation.

According to this study, the apparent ileal digestible amino acid intake is a better predictor of performance and carcass responses than is either total or apparent faecal digestible amino acid intake. This is in agreement with the theory of the site of digestion processes and the results of most earlier experiments conducted on the same topic. The cost and laboriousness of ileal digestibility assays make them difficult to use as a routine procedure. Consequently, future research should aim to develop cheaper methods, e.g. in vitro assays, to predict the digestibility values of the feeds used in diet formulation.

Acknowledgements. The author is grateful to the Swine Research Station of the Agriculture Research Centre for providing the data for the investigation. Financial support was received from the Ministry of Agriculture and Forestry.

\section{References}

AlAVIUHKolA, T. 1989. Lihaluurehujauho sikojen rehuna. Lihayhtymän tiedotuslehti 2: 15-16.

ANDERSEN, P.E. \& JUST, A. 1983. Tabeller over foderstoffers sammensættning m.m. Kvæk Svin. S.L. Mollers Bogtryk. København. 102 p.

BATTERHAM, E.S. 1992. Availability and utilization of amino acids for growing pigs. Nutrition Research Reviews 5: 1-18.

-, Andersen, L.M., Baigent, D.R., Beech, S.A. \& ElLIOTT, R. 1990a. Utilization of ileal digestible amino acids by pigs: lysine. British Journal of Nutrition 64 : 679-690.

-, Andersen, L.M., Baigent, D.R., Darnell, R.E. \& TAVERNER, M.R. 1990b. A comparison of the availability and ileal digestibility of lysine in cottonseed and soya-bean meals for grower/finisher pigs. British Journal of Nutrition 64: 663-667.

-, Murison, R.D. \& LowE, R.F. 1981. Availability of lysine in vegetable protein concentrates as determined by the slope-ratio assay with growing pigs and rats and by chemical techniques. British Journal of Nutrition 45: 401-410.

Conway, D., Sauer, W.C., Den Hartog, L.A. \& HuisMAN, J. 1990. Studies on the threonine requirements of growing pigs based on the total, ileal and faecal digestible contents. Livestock Production Science 25: 105-120.

CVB 1991. Veevoedertabel. Runderveg 6, 8219 pk Lelystad, The Netherlands. ISBN 90-72839-13-7.

Dierick, N.A., Vervaeke, I.J., Decuypere, J., VAn Der HeYde, H. \& HendRICKS, H.K. 1988. Correlation between ileal and fecal digested protein and organic matter to production performance in growing pigs. EAAP Publication 35. Proc. 5th Int. Symp. on Protein Metabolism and Nutrition, Vol. 37, Rostock, GDR. p. 50-51.

HANRAHAN, T.J. 1989. The response of growing pigs to lysine. The Feed Compounder No 7: 32-39.

Jørgensen, H., FernándeZ, J.A. \& Just, A. 1985. Relationship between ileal and faecal digestible nutrients in 96 diets for pigs. In: Just, A. et al. (eds.). Proceedings of the 3rd International Seminar on Digestive Phys- iology in the Pig, Copenhagen, Denmark. p. 352-355.

-, SAUER, W.C. \& ThACKER, P.A. 1984. Amino acid availabilities in soybean meal, sunflower meal, fish meal and meat and bone meal fed to growing pigs. Journal of Animal Science 58: 926-934.

Just, A., Jørgensen, H. \& FernándeZ, J.A. 1985. Correlation of protein deposited in growing female pigs to ileal and faecal digestible crode protein and amino acids. Livestock Production Science 12: 145-159.

Knabe, D.A., La Rue, D.C., GregG, E.J., Martinez, G.M. \& TANKSLEY, T.D., JR. 1989. Apparent digestibility of nitrogen and amino acids in protein feedstuffs by growing pigs. Journal of Animal Science 67: 441-458.

Laplace, J.P., Darcy-Vrillon, B., Pérez, J.M., HenRY, Y., Giger, S. \& SaUVAnt, D. 1989. Associative effects between two fibre sources on ileal and overall digestibilities of amino acids, energy and cell-wall components in growing pigs. British Journal of Nutrition 61: 75-87.

Low, A.G., Partridge, I.G., Keal, H.D. \& Jones, A.R. 1982. A comparison of methods in vitro and in vivo of measuring amino acid digestibility in foodstuffs as predictors of pig growth and carcass composition. Animal Production 34: 413 (abstr.).

Madsen, A., Petersen, J., Mortensen, H.P., BejerhOLM, C. \& BARTON, P. 1991. Protein til han- og sogrise. Stigende mængder sojaskrå. Statens Husdyrbrugsforsøg. Meddelelse 795. 6 p.

MASON, V.C. 1984. Metabolism of nitrogenous compounds in the large gut. Proceedings of the Nutrition Society 43: 45-53.

Moughan, P.J. 1991. Towards an improved utilization of dietary amino acids by the growing pigs. In: Haresign, W. \& Cole, D.J.A. (eds.). Recent advances in animal nutrition. Butterworth-Heinemann, Oxford. p. 45-64.

- \& SMITH, W.C. 1985. Determination and assessment of apparent ileal amino acid digestibility coefficients for the growing pigs. New Zealand Journal of Agricultural Research 30: 183-187.

-, Smith, W.C., Pearson, G. \& James, K.A.C. 1991. Assessment of apparent ileal lysine digestibility for use 
in diet formulation for growing pigs. Animal Feed Science and Technology 34: 95-109.

SAlo, M.-L., TuORI, M. \& KIISKINEN, T. 1990. Rehutaulukot ja ruokintanormit. 70 p. Helsinki.

SAS 1990. SAS/STAT User's Guide, Version 6, 5 th Ed., Vol. 2. 795 p. SAS Institute Inc, Cary, NC, USA.

SAUER, W.C. \& OzimeK, L. 1986. Digestibility of amino acids in swine: results and their practical applications. A review. Livestock Production Science 15: 367-388.

SiLJANDER-RASI, H. 1993. Rypsirouhe sopii sialle. Sika 23: 14-15.

Suomi, K. \& Immonen, I. 1989. Kotimaiset valkuaisrehut puntarissa. Sika 20: 28-29.

TANKSLEy, T.D. JR. \& KNABE, D.A. 1984. Ileal digestibilities of amino acids in pig feeds and their use in formulating diets. In: Haresigh, W. \& Cole, D.J.A. (eds.). Recent advances in animal nutrition. Butterworths, Lon- don. p. 75-95.

Valaja, J., Suomi, K., Alaviuhrola, T. \& Immonen, I. 1992. Effect of dietary fish meal on the palatability and fatty acid composition of pork. Agricultural Science in Finland 1: 21-26.

Wang, T.C. \& Fuller, M.F. 1990. The effect of the plane of nutrition on the optimum dietary amino acid pattern for growing pigs. Animal Production 50: 155-164.

Wiseman, J., Jagger, S., Cole, D.J.A. \& Haresign, W. 1991. The digestion and utilization of amino acids of heat-treated fish meal by growing/finishing pigs. Animal Production 53: 215-225.

ZebrowsKA, T. 1973. Digestion and absorption of nitrogenous compounds in the large intestine of pigs. Roczniki Nauk Rolniczych Series B95, 3: 85-89.

Manuscript received February 1994

\title{
SELOSTUS
}

\section{Eri tavoin laskettu valkuaisen ja aminohappojen saanti lihasikojen tuotantotulosten selittäjänä}

\author{
JARMO VALAJA
}

Helsingin yliopisto

Selvityksessä verrattiin eri tavoin laskettujen raakavalkuaisen ja aminohappojen saantien luotettavuutta lihasikojen tuotantotulosten selittäjinä. Tutkimus oli osa maaja metsätalousministeriön käynnistämää rehutaulukoiden uudistusprojektia. Aineistoksi valittiin viisi lihasikojen ruokintakoetta Maatalouden tutkimuskeskuksen sikatalouden tutkimusasemalta. Rehun koostumustietojen sekä kirjallisuudesta saatujen sulavuuskertoimien perusteella laskettiin ruokintaryhmien päivittäinen sulavan raakavalkuaisen ja tärkeimpien välttämättömien aminohappojen, lysiinin, metioniinin ja treoniinin, kokonaissaanti sekä ko. aminohappojen kokonaissulava tai ohutsuolessa sulava osuus. Valkuaisen ja aminohappojen saanteja verrattiin ruokintaryhmien tuotantotuloksiin (päivăkasvu ja rehuhyötysuhde) ja teuraslaatuparametreihin (selkä- ja kylkisilavan paksuus, koko ruhon sekä sen arvokkaiden osien lihaprosentti).

Päivittäisellä sulavan raakavalkuaisen saannilla ei pystytty selittämään eroja sikojen tuotantotuloksissa tai teuraslaadussa. Osa syynä tähän oli, että neljăssä kokeessa viidestä oli ruokintaryhmien sulavan raakavalkuaisen saanti tasattu. Aminohappojen, erityisesti lysiinin, pãivittäiset saannit selittivät varsin hyvin tuotantotulosten muutoksia. Korrelaatiokertoimet olivat suurimpia eri tavoin laskettujen lysiinin saantien sekä päiväkasvun välillä. Ohutsuolessa sulava aminohappojen saanti selitti kokonais- tai sontasulavaa saantia paremmin tuotantotulosten ja teurasparametrien muutokset. Ero oli suurin rehuhyötysuhteessa sekä selkä- ja kylkisilavan paksuudessa. Myös regressioyhtälöihin ohutsuolisulavan lysiinin saanti sopi paremmin kuin lysiinin kokonais- tai kokonaissulava saanti. Ohutsuolessa sulavan lysiinin saanti selitti paremmin rehuhyötysuhteen, selkä- ja kylkisilavan paksuuden sekä ruhon arvokkaiden osien lihaprosentin muutoksia verrattuna lysiinin kokonais- tai kokonaissulavaan saantiin (selkäsilavan paksuudessa ainostaan kokonaissulavan lysiinin saanti heikompi). Selvitys vahvistaa käytännössä ohutsuolisulavuuskertoimien paremmuuden rehujen valkuaisen laadun arvioimisessa. 